\title{
The Novel $p s$ and $p s-2$ Specific Markers for Selection of Functional Male Sterile Tomato Lines in Breeding Programs and Hybrids Seed Production
}

\author{
Mirosława Staniaszek ${ }^{1}$, Katarzyna Szajko ${ }^{2}$, Elżbieta U. Kozik ${ }^{1}$, Marzena Nowakowska ${ }^{1} \&$ Waldemar Marczewski ${ }^{2}$ \\ ${ }^{1}$ Research Institute of Horticulture, Konstytutcji, Skierniewice, Poland \\ ${ }^{2}$ Plant Breeding and Acclimatization Institute, National Research Institute, Młochów, Platanowa, Młochów, \\ Poland \\ Correspondence: Mirosława Staniaszek, Research Institute of Horticulture, Konstytutcji 3 Maja 1/3 str., 96-100 \\ Skierniewice, Poland. Tel: 48-46-833-2211. E-mail: mstan@iwarz.pl
}

Received: May 14, 2012 Accepted: June 13, 2012 Online Published: August 24, 2012

doi:10.5539/jas.v4n10p61 URL: http://dx.doi.org/10.5539/jas.v4n10p61

The research was supported by the National Center of Scientific Research and Development, project R12020 03 and Ministry of Agriculture and Rural Development, project DHOR 97

\begin{abstract}
Functional male sterility in tomato (Solanum lycopersicum L.), controlled by the $p s-2$ and ps genes can be utilized in the production of $F_{1}$ hybrid tomato seed. Two novel cleaved amplified polymorphic sequence (CAPS) markers linked to the $p s-2$ and $p s$ genes were found in tomato. The C4-30 and C2-21 markers were developed based on the conserved ortholog set II (COSII) sequences C2_At3g20020 and C2_At1g65900 located on tomato chromosomes 4 and 2, respectively. The HinfI-derived PCR restriction product C4-30 80 was applicable in the detection of functional male sterile plants. In case of the C2-21 marker, a polymorphism was revealed after digestion of the amplicon with restriction enzyme $\mathrm{MboI}$. Specificity of the DNA markers identified was verified by scoring the tomato parental lines, $\mathrm{F}_{2}$ progeny and $\mathrm{F}_{1}$ hybrids, in which maternal lines possessed the $p s$ or $p s-2$ gene. C4-30 and C2-21 can be used as the diagnostic tools in tomato breeding programs and in $\mathrm{F}_{1}$ hybrid seed production.
\end{abstract}

Keywords: Solanum lycopersicum L., CAPS markers, functional male sterility, marker assisted selection (MAS)

\section{Introduction}

Traditional methods of $\mathrm{F}_{1}$ hybrid tomato (Solanum lycopersicum L.) seed production require manual emasculation of the flowers in the early bud stage. Using female lines possessing the trait of functional male sterility controlled by recessive $p s$ and $p s-2$ genes can reduce the time and cost of such work (Potaczek \& Kubicki, 1986; Atanassova, 1999 \& 2000; Staniaszek et al., 2000). Several tomato $\mathrm{F}_{1}$ hybrids exhibiting functional sterility controlled by the $p s$ gene, have been developed at the Research Institute of Horticulture in Skierniewice, Poland. They have been introduced into practical applications and commercial production (Staniaszek et al., 2000 \& 2002; Kozik \& Nowakowska, 2007). In Bulgaria, thirteen $\mathrm{F}_{1}$ hybrids were developed based on functional sterility controlled by the $p s$ - 2 gene (Atanassova, 1999). Significant progress in breeding new tomato $\mathrm{F}_{1}$ hybrids has been made in the Czech Republic and Moldova (Atanassova, 1999). Unfortunately, the occurrence of selfings can in practice limit the application $p s$ and $p s-2$ sterility. The percentage of selfings, which depends on the temperature and humidity, is highest under high temperature conditions (Simonov, 1967; Atanassova, 2000). The recessive gene ps-2 (positional sterility-2), described in Czech cultivar Vrbicanske nizke, is responsible for functional male sterility in tomato (Tronickova, 1962; Atanassova 1991 \& 1999 \& 2000). Plants homozygous for the ps-2 allele exhibit pollen maturation but are sterile for mechanical reasons. The recessive gene ps (positional sterility) confers another type of functional male sterility in tomato. Positional sterility - ps is manifested by flowers with non-splitting anthers, corolla petals accreting to androecium at $2 / 3$ of their length (Potaczek \& Kubicki, 1986). This form of sterility has been identified by Larson and Paur in 1940 in the tomato cultivar John Baer (Larson \& Paur, 1948; Potaczek, 1984; Atanassowa, 2000). Expression of these two forms of sterility strongly depends on environmental conditions (reviewed in Atanassova, 1999). 
The $p s-2$ gene was localized in map segment T0958 -T0635 on tomato chromosome 4 (Gorguet et al., 2006), whereas the $p s$ gene is closely linked to aw (anthocyanin without) gene on chromosome 2 (Dorossiev, 1976; Tanksley et al., 1992; Atanassova, 2000). Based on single nucleotide polymorphism (SNP), Gorguet and co-workers (2009) developed the ps-2 marker, which was applied towards in the screening of 176 tomato breeding lines, 8 of them were $p s-2 / p s-2$. Using the AFLP method and $\mathrm{F}_{2}$ segregated population derived from the Bulgarian lines CMC1ps2, Li et al. (2006) indicated three markers E37/M47, E38/M48 and E33/M50 - useful in the identification of fertile lines. Recently, two co-dominant markers: microsatellite SSR450 and CAPS marker developed from the sequence RFLP TG123, were found to be linked with the $p s-2$ gene (Sha et al., 2010). These markers were successfully tested in $123 \mathrm{~F}_{2}$ plants (Sha et al., 2010). Staniaszek et al. (2000) described three RAPD markers, OPH04-670, OPAX10-780 and OPW13-1230, linked to the $p s$ locus. OPAX10-780 and OPW13-1230 were specific to the fertile male parent and can be used for distinguishing true hybrids from self-pollination of the female parents. OPH04-670 was of use in the identification of functionally male sterile lines possessing the $p s$ gene. However, co-dominant molecular markers for the $p s$ gene need to be identified.

Here, we report two novel co-dominant diagnostic PCR markers, C4-30 and C2-21, for selection of ps-2 and ps functional male sterile tomato lines, respectively.

\section{Materials and Methods}

\subsection{Plant Material}

The $p s-2$ male sterile line M 3089 obtained after inbreeding and selection of line Start 24, was kindly provided by B. Atanassova, Institute of Genetics “Acad. Doncho Kostoff”, Bulgarian Academy of Science, Sofia, Bulgaria (Kozik \& Nowakowska, 2007). M 3089 was crossed with a male fertile line M 3372, which was selected by eight generations of inbreeding of the $F_{1}$ hybrid 7-2-92 (Rijk Zwaan B.V., The Netherlands). The single $F_{1}$ plant mating was self-pollinated to produce the $131 \mathrm{~F}_{2}$ progeny.

The second $\mathrm{F}_{2}$ population of 119 plants was generated from $\mathrm{F}_{1}$ derived from the highly inbred tomato $p s$ line $\mathrm{W}$ 1.8a (ps line) and the fertile line M 4191 (selected from Pearly $\mathrm{F}_{1}$ hybrid, DAPco B.V., The Netherlands). The $p s$ sterile line W 1.8a was generated from a cross between line PH 1106 (ps) and S. chilense LA 1969 (Potaczek, 1999; Kozik \& Nowakowska, 2007).

Two ps-2 male sterile lines M 3090 and M 3091 (selected from line Start 24), 13 F $_{1}$ hybrids: E1231, E1233, E1235, E1236, E1237, E1240, E1241, E1242, E1243, E1244 (derived from Department of Genetics, Breeding and Biotechnology, Research Institute of Horticulture, Skierniewice, Poland), Elina, Odysseus, Prekoz (Institute of Genetics “Acad. Doncho Kostoff”, Bulgarian Academy of Science, Sofia, Bulgaria) and two male fertile lines M 3586, M 3597 (selected by eight generations of inbreeding from Daniela $F_{1}$, Hazera Genetics, Israel and Monika $\mathrm{F}_{1}$, Syngenta Seeds B.V., The Netherlands, respectively) were used for the presence of the $p s-2$ linked marker C4-30 (Table 1).

Table 1. Distribution of the restriction fragments of the marker C4-30 in tomato breeding lines and $\mathrm{F}_{1}$ hybrids

\begin{tabular}{|c|c|c|c|}
\hline \multirow{2}{*}{$\mathrm{F}_{1}$ hybrids/breeding lines } & \multirow{2}{*}{ Origin } & \multicolumn{2}{|c|}{ C4-30 restriction fragments } \\
\hline & & $80 \mathrm{bp}$ & $190 \mathrm{bp}$ \\
\hline E1231 $F_{1}$, E1233 $F_{1}$ E1235 $F_{1}$, E1236 $F_{1}$ E1237 $F_{1}$, & 1 & + & + \\
\hline E1240 $F_{1}, E 1241 F_{1}, E 1242 F_{1}, E 1243 F_{1}, E 1244 F_{1}$, & & & \\
\hline Odysseus $\mathrm{F}_{1}$, Elina $\mathrm{F}_{1}$, Prekoz $\mathrm{F}_{1}$ & 2 & + & + \\
\hline M 3090, M 3091 & 1 & + & - \\
\hline M 3586, M 3597 & 1 & - & + \\
\hline
\end{tabular}

1 Department of Genetics, Breeding and Biotechnology, Research Institute of Horticulture Skierniewice, Poland;

2 Institute of Genetics 'Acad. D. Kostoff', Bulgarian Academy of Sciences Sofia, 1113, Bulgaria, (B. Atanassova).

+ presence of marker

- absence of marker

The $p s$-specific marker C2-21 was tested in six male sterile lines: $\mathrm{W} 1.5, \mathrm{~W} 1.11 \mathrm{a}$ (made from a cross between the line PH1106 and S. chilense, Department of Genetics, Breeding and Biotechnology, Research Institute of Horticulture Skierniewice, Poland), 16, 17, 18, 19 (Seeds \& Breeding Company PNOS, Ożarów Maz, Reguły, Poland), $12 \mathrm{~F}_{1}$ hybrids: E11.93, E12.09, E936, Remiz $\mathrm{F}_{1}$, Perkoz $\mathrm{F}_{1}$, Bekas $\mathrm{F}_{1}$, Słonka $\mathrm{F}_{1}$ (Department of Genetics, Breeding and Biotechnology, Research Institute of Horticulture, Skierniewice, Poland), 13/06, 17/06, 22/06, 
31/06, 101/06 (Seeds \& Breeding Company PlantiCo, Zielonki, Gołębiew, Poland) and two fertile lines M 4156 (selected from Colibri $F_{1}$, Clause Vegetable Seeds, France), M 4157 (selected from Fuensanta $F_{1}$, Seminis Vegetable Seeds, Inc., USA), (Table 2).

Table 2. Distribution of the restriction fragments of the marker C2-21 in tomato breeding lines and $F_{1}$ hybrids

\begin{tabular}{|c|c|c|c|}
\hline \multirow{2}{*}{$\begin{array}{c}\mathrm{F}_{1} \text { hybrids/ } \\
\text { breeding lines }\end{array}$} & \multirow{2}{*}{ Origin } & \multicolumn{2}{|c|}{$\mathrm{C} 2-21$ restriction fragments } \\
\hline & & $380 \mathrm{bp}$ & $420 \mathrm{bp}$ \\
\hline $\begin{array}{l}\text { E11.93 } F_{1}, \text { E12.09F } F_{1} \text {, E936 } F_{1} \text {, Remiz } F_{1} \text {, } \\
\text { Perkoz } F_{1} \text {, Bekas } F_{1} \text {, Słonka } F_{1}\end{array}$ & 1 & + & + \\
\hline $\begin{array}{l}13 / 06 \mathrm{~F}_{1}, 17 / 06 \mathrm{~F}_{1} \\
22 / 06 \mathrm{~F}_{1}, 31 / 06 \mathrm{~F}_{1} \\
101 / 06 \mathrm{~F}_{1}\end{array}$ & 2 & + & + \\
\hline $16,17,18,19$ & 3 & + & - \\
\hline W 1.5, W $1.11 \mathrm{a}$ & 1 & + & - \\
\hline M 4156, M 4157 & 1 & - & + \\
\hline
\end{tabular}

1 Department of Genetics, Breeding and Biotechnology, Research Institute of Horticulture, Skierniewice, Poland;

2 Seeds \& Breeding Company PlantiCo, Zielonki, Gołębiew, Poland;

3 Seeds \& Breeding Company PNOS, Ożarów Maz, Reguły, Poland.

+ presence of marker

- absence of marker

Plants were grown in a greenhouse. Young, fresh leaves from parental lines, breeding lines, $\mathrm{F}_{1}$ hybrids (10 plants per each genotype) and two $\mathrm{F}_{2}$ populations segregating for the $p s-2$ and $p s$ were harvested and stored at $-70^{\circ} \mathrm{C}$ until DNA extraction.

\subsection{Expression of ps-2 and ps-Deriving Sterility}

Expression of $p s-2$ and $p s$-deriving sterility was observed on each $\mathrm{F}_{2}$ plant. Plants were classified functionally male sterile when no selfed seeds were found in the fruits. Segregation data were analyzed by the Chi-square $\left(\chi^{2}\right)$ test.

\subsection{DNA Extraction}

Total DNA was isolated from frozen young tomato leaves of each plant using DNeasy Plant Mini Kit (Qiagen $\mathrm{GmbH}$, Hilden, Germany). DNA concentration and purity was determined spectrophotometrically and by visualization on a $0.8 \%$ agarose gel.

\subsection{PCR Primers Design, PCR Amplification, Restriction Protocol and Electrophoresis}

The CAPS marker C4-30 was developed based on a conserved ortholog set II (COSII) sequence C2_At3g20020 (Solanaceae Genome Network, SGN; www. solgenomics.net), which was positioned at $19.8 \mathrm{cM}$ on tomato chromosome 4 (Tomato-EXPEN 2000, SGN), (Wu et al., 2006). The CAPS marker C2-21 was obtained based on sequences $\mathrm{C} 2$ At1g65900 specific for tomato chromosome 2. Forward and reverse primers sequences were: $\mathrm{f}$ : 5'-ATGTTACAACCAACAGACGGCGG-3'; r: 5'-TGAAGTTTTGATGCTGAAAAATTGC-3' for C4-30 and f: 5' TGTGGTGCATTCAGAGTTTAGAC 3', r: 5' GAGGCCACGTATGTTGATGT 3' for C2-21.

PCR was performed in $20 \mu \mathrm{l}$ of $20 \mathrm{mM}$ Tris- $\mathrm{HCl} \mathrm{pH} 8.4,50 \mathrm{mM} \mathrm{KCl}, 1.5 \mathrm{mM} \mathrm{MgCl}, 0.1 \mathrm{mM}$ of each deoxynucleotide, $0.2 \mu \mathrm{M}$ of each primer, containing 1U Taq DNA Polymerase (Invitrogen, Carlsbad, CA, USA) and $30 \mathrm{ng}$ genomic DNA as template. The PCR parameters were: initial denaturation at $94^{\circ} \mathrm{C}$ for $60 \mathrm{~s}$ followed by 40 cycles of denaturation at $93^{\circ} \mathrm{C}$ for $15 \mathrm{~s}$, annealing at $55^{\circ} \mathrm{C}$ for $20 \mathrm{~s}$ and extension at $72^{\circ} \mathrm{C}$ for $60 \mathrm{~s}$. A final extension was at $72^{\circ} \mathrm{C}$ for $5 \mathrm{~min}$. The GeneAmp 9700 thermal cycler was used for DNA amplification.

Amplicon C4-30 was digested with restriction enzyme Hinf1 (MBT Fermentas, Lithuania), whereas C2-21 product was treated with $\mathrm{MboI}$ (MBT Fermentas, Lithuania). Digestion of PCR products were carried out at $37^{\circ} \mathrm{C}$ for $3 \mathrm{~h}$ in a $20 \mu \mathrm{l}$ mixture containing $5 \mathrm{U}$ of restriction enzyme, $18 \mu \mathrm{l}$ PCR product and 10x concentrated restriction enzyme buffer. 
Restriction products were visualized by electrophoresis in 1.4\% agarose (Sigma-Aldrich, USA) gel and 3.5\% MetaPhor agarose (Lonza, Rockland, ME, USA) in 1xTBE (tris-borate-EDTA) buffer after staining with ethidium bromide.

\section{Results and Discussion}

\subsection{Identification of the CAPS Marker C4-30 Linked to Locus ps-2}

PCR product C4-30 of approximately 1000 bp was amplified in male sterile and fertile plants (not shown). The CAPS fragment of about 80 bp was found in the homozygous male sterile line M 3089 (Figure 1, lane 1), whereas the restriction product of about $190 \mathrm{bp}$ was identified in the homozygous male fertile line M 3372 (Figure 1, lane 2) after HinfI digestion and electrophoresis in 3.5\% MetaPhor agarose gel.

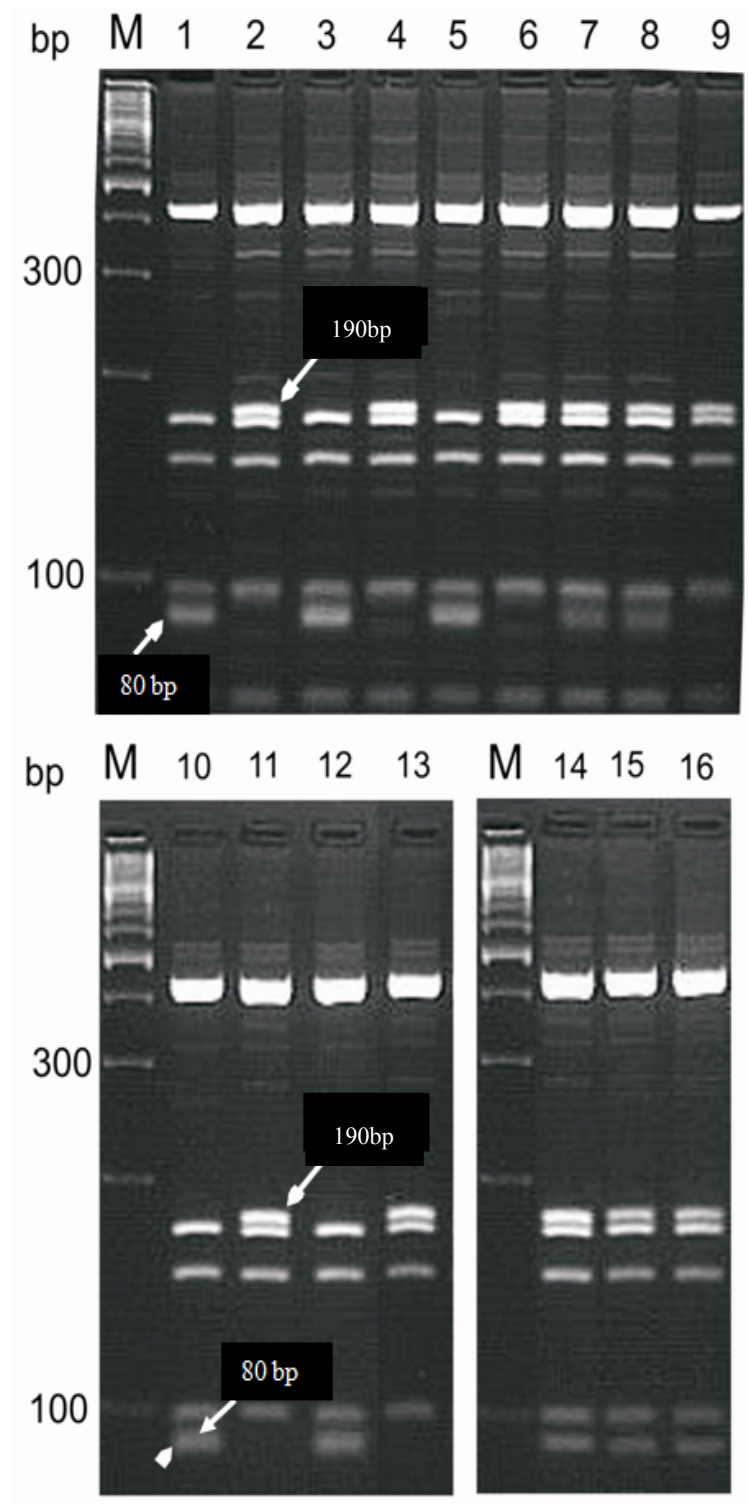

Figure 1. Electrophoretic patterns of the CAPS marker C4-30 linked to the tomato gene $p s-2$ after digestion with HinfI Lanes 1, 10 and 12 show ps-2-homozygous sterile lines M 3089, M 3090 and M 3091, respectively.

Lanes 2, 11 and 13 contain $p s$-2-homozygous fertile lines M 3372, M 3586 and M 3597, respectively.

Lanes 3 - 9 show restriction patterns for $\mathrm{F}_{2}$ progeny.

Lanes $14-16$ are for $F_{1}$ hybrids Prekoz, Odysseus and Elina, respectively.

M - 100 bp DNA ladder (MBT Fermentas, Lithuania). 
The segregation of sterile and fertile plants was $35: 96$ in the $\mathrm{F}_{2}$ progeny, which is in agreement with a ratio of 1 : $3\left(\chi^{2}=0.16, P=0.69\right)$. The marker $\mathrm{C} 4-30_{80}$ was detected in all $35 \mathrm{~F}_{2}$ sterile plants. In the group of $96 \mathrm{~F}_{2}$ fertile plants 35 were homozygous for C4-30 190 , whereas both restriction products were observed in 61 plants. The restriction patterns of amplicon C4-30 for $7 \mathrm{~F}_{2}$ progeny are shown in Figure 1, where lanes 3 and 5 are for homozygous sterile plants, lanes 4, 6 and 9 show homozygous fertile plants and lanes 7 and 8 are for $p s-2$ heterozygous plants. The marker C4-30 was also of relevance for the detection of $p s-2$ homozygosity in the sterile (M 3090 and M 3091) and fertile (M 3586 and M 3597) tomato lines (Figure 1, lanes 10, 12, 11 and 13, respectively), as well as for $3 \mathrm{~F}_{1}$ hybrids: Prekoz, Odysseus and Elina provided by B. Atanassova (Figure 1, lanes 14,15 and 16 , respectively). $\mathrm{C} 4-30_{80}$ and $\mathrm{C} 4-30_{190}$ were present in $10 \mathrm{~F}_{1}$ hybrids generated in a tomato breeding program at the Research Institute of Horticulture, Skierniewice, Poland. These results were summarized in Table 1.

The presented study indicates that the marker C4-30 shows a high ps-2 - selection specificity. These results show that the marker C4-30 can simplify the screening of functional male sterile lines in tomato breeding programs and hybrid seed production.

\subsection{Identification CAPS Marker Linked to Locus ps}

A 1800 bp PCR marker C2-21, was amplified in all parental lines and $F_{1}$ plants (not shown). Polymorphism of this amplicon was revealed after digestion with restriction enzymes $M b o \mathrm{I}$ and electrophoresis in 1.4\% agarose gel. The restriction fragment of $380 \mathrm{bp}$ was found in sterile lines with gene $p s$ (Figure 2, lanes 1,3,5), whereas $420 \mathrm{bp}$ long fragment was observed in fertile lines (Figure 2, lanes 2, 4, 6). The heterozygous genotypes $F_{1}$ plants were given three fragments, 380,420 and $580 \mathrm{bp}$. The third fragment of $580 \mathrm{bp}$ from the heterozygous plants was shown to be a heteroduplex between the two fragments 380 and $420 \mathrm{bp}$ (Figure 2, lanes 7-9).

Restriction products were analyzed in 119 plants of the segregating $F_{2}$ population. In the $F_{2}$ population, segregation of sterile and fertile plants was 24:95. A chi square $\left(\chi^{2}\right)$ test confirmed a 1:3 segregation of sterile to fertile individuals $\left(\chi^{2}=1.48, P=0.22\right)$. The $p s$ specific restriction fragment of $380 \mathrm{bp}$ was detected in 24 functionally male sterile $\mathrm{F}_{2}$ plants. Among the $95 \mathrm{~F}_{2}$ fertile plants 37 were homozygous for $\mathrm{C} 2-21_{420}$, whereas three restriction products were observed in 58 plants (Figure 2, lines 10-23).

To confirm this marker as a good diagnostic tool for marker-assisted selection, 20 genetically diverse tomato lines and $\mathrm{F}_{1}$ hybrids were tested (Table 2). C2-21 was applicable for the detection of ps homozygosity in the sterile tomato lines: W 1.5, W 1. 11a (Figure 2, lanes 3, 5), 16, 17, 18 and 19 (Table 2). C2-21 $380, \mathrm{C} 2-21_{420}$ and C2-21 $1_{580}$ were revealed in $12 \mathrm{~F}_{1}$ hybrids generated in the tomato breeding programs, (Table 2, Figure 2, lanes 7-9), whereas the marker C2-21 380 was not observed in fertile lines M 4156 and M 4157 (Table 2, Figure 2, lanes 4, 6).

The functional male sterility in tomato controlled by recessive gene $p s$ and $p s-2$ is the important trait in $\mathrm{F}_{1}$ hybrids seed production. Identification of functionally male sterile plants is labour - consuming, it is possible only during of flowering time or on based the number of seeds per fruit (Potaczek \& Kubicki, 1986; Staniaszek et al., 2000, 2002). Molecular markers associated with genes $p s$ and $p s-2$ may be helpful for the identification functionally male sterility. The RAPD AFLP and CAPS markers were used to identify locus $p s$ and $p s-2$ (Staniaszek et al., 2000; Li et al., 2006; Gorguet et al., 2009). RAPD is relatively simple and easy molecular technique, highly discriminate for genetic polymorphism in tomato, but they are dominant and poor reproducibility (Jones et al., 1997). On the other hand the use of AFLP markers for marker-assisted selection (MAS) is very time consuming and expensive. Because of recombination events different molecular tools should be used for MAS in breeding practice.

The results of this study demonstrate that the new CAPS markers C4-30 and C2-21 may be helpful for the identification of the $p s-2$ and $p s$ genes, respectively. Both markers are co-dominant, the heterozygous genotype can be distinguished from the dominant or recessive homozygous individuals. They can be used in marker assisted selection of the functional male sterility in tomato plants. 

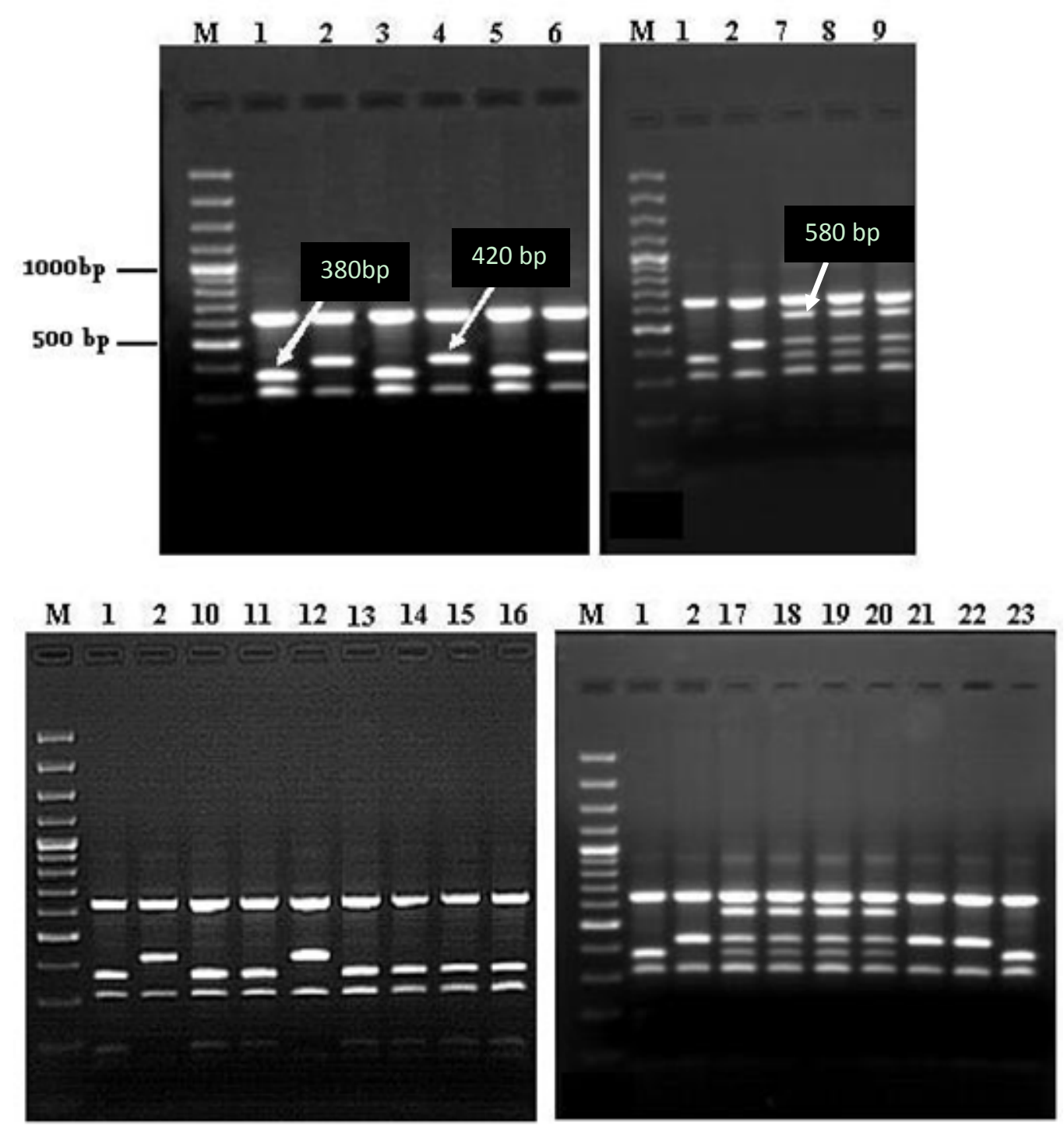

Figure 2. Electrophoretic patterns of the CAPS marker C2-21 linked to the tomato gene $p s$ after digestion with $M b o$ I Lanes 1, 3 and 5 show $p s$ homozygous sterile lines W 1.8a, W 1.5 and W 1.11a, and respectively.

Lanes 2, 4, and 6 contain ps-2-homozygous fertile lines M 4191 M 4156 and M 4157, respectively.

Lanes 7, 8, 9 - are for $\mathrm{F}_{1}$ hybrids E 11.93, E 12.09, E 936 respectively.

Lines 10-23 show restriction patterns for $\mathrm{F}_{2}$ progeny.

M - 100 bp DNA ladder (MBT Fermentas, Lithuania).

\section{References}

Atanassova, B. (1991). Localization of tomato ps-2 gene (functional sterility). Rep. Tomato. Genet. Coop., 41, 12.

Atanassova, B. (1999). Functional male sterility (ps-2) in tomato (Lycopersicon esculentum Mill.) and its application in breeding and hybrid seed production. Euphytica, 107, 13-21.

Atanassova, B. (2000). Functional male sterility in tomato (Lycopersicon esculentum Mill.) and its application in hybrid seed production. Acta Physiologiae Plantarum, 22(3), 221-224.

Dorossiev, L. (1976). Use of mutant forms in the development of lines for tomato hybrid seed production. In Experimental mutagenesis in plants. Proc's of the Intl. Symp. on Experimental mutagenesis in plants. Varna, Bulgaria, 370-375. 
Gorguet, B., Schipper, D., van Heusden, A. W., \& Lindhout, P. (2006). High resolution fine mapping of $p s-2$, a mutated gene conferring functional male sterility in tomato due to non-dehiscent anthers. Theor. Appl. Genet., 113, 1437-1448. http://dx.doi.org/10.1007/s00122-006-0389-9

Gorguet, B., Schipper, D., van Lammeren, A., Visser, R. G. F., \& van Heusden, A. W. (2009). ps-2, the gene responsible for functional sterility in tomato, due to non-dehiscent anthers, is the result of a mutation in a novel polygalacturonase gene. Theor. Appl. Genet., 118, 1199-1209. http://dx.doi.org/10.1007/s00122-009-0974-9

Jones, C. J., Edwards, K. J., Castaglione, S., Winfield M. O., Sala, F., Wiel, C. van de., ... Karp, A. (1997). Reproducibility testing of RAPD, AFLP and SSR markers in plants by a network of European laboratories. Mol. Breed, 3, 381-390.

Kozik, E. U., \& Nowakowska, M. (2007). Changes in stability of $p s$ and $p s-2$ functional male sterile lines of tomato. In Spontaneous and induced variation for the genetic improvement of horticultural crops. Pawel Nowaczyk (Eds.), University of Technology and Life Sciences Press, Bydgoszcz, 233-238.

Larson, R. E., \& Paur, S. (1948). The description and the inheritance of a functionally sterile flower mutant in tomato and its probable value in hybrid tomato seed production. Proc. Am. Soc. Hort. Sci, 355-364.

Li, J., Zhu, S., Song, Y., Zhang, Z., Atanassova, B., Zhang, S., \& Xu, H. (2006). Development of AFLP molecular markers tightly linked with ps 2 loci in tomato. Journal of Plant Genetic Resources, 7(1), 35-38. (in Chinese with an English abstract).

Potaczek, H. (1984). Wykorzystanie funkcjonalnej sterylności w hodowli heterozyjnej pomidora szklarniowego. The use of functional sterility in heterosis breeding of greenhouse tomato. Nowości Warzywnicze, 5, 5-13 (in Polish)

Potaczek, H., \& Kubicki, B. (1986). Functional male sterility and heterostyly of cultivated tomato (Lycopersicon esculentum Mill.). Genetica Polonica, 27(3-4), 309-314.

Potaczek, H. (1999). Progress in breeding of male sterile lines $p s$ for $F_{1}$ tomato hybrid seed production. Proceeding of the VIII Scientific Horticulture Plant Breeding Symposium. In Horticulture Plant Breeding to start with XXI century. University of Agriculture in Lublin, 9-11. (in Polish with an English summary).

Sha, Z., Yan, S., Lei, L., Atanassova, B., He-jin, X., Guo-long, Z., \& Jun-ming, L. (2010). Development of SSR and CAPS molecular markers linked with ps-2 gene in tomato. Acta Horticulture Sinica, 37(2), 235-240. (in Chinese with an English abstract).

Simonov, A. A. (1967). Obtaining sterile counterparts in tomato by backcrossing. Dokl. Skad. Selshoz. Nauk, 12, 13-16. (in Russian).

Staniaszek, M., Marczewski, W., Habdas, H., \& Potaczek, H. (2000). Identification of RAPD markers linked to the ps gene and their usefulness for purity determination of breeding lines and $\mathrm{F}_{1}$ tomato hybrids. Acta Physiol. Plantarum, 22(3), 303-306

Staniaszek, M., Marczewski, W., \& Kozik, E. U. (2002). Evaluation of genetic purity of tomato F $_{1}$ hybrids using RAPD method. Veged. Crops Res. Bull, 56, 17-23

Tanksley, S. D., Ganal, M. W., Prince, J. P., de Vicente, M. C., Bonierbale, Broun, P., Fulton, T. M., ... Young, N. D. (1992). High density molecular linkage maps of the tomato and potato genomes. Genetics, 132, 1141-1160.

Tronickova, E. (1962). New type of functional male sterility in tomato. Ved. Prace Vysk. Ust. Rostl. Vyr. Praha-Ruzine, 6, 29-39 (in Czech)

Wu, F., Mueller, L.A., Crouzillat, D., Pétiard, V., \& Tanksley, S. D. (2006). Combining bioinformatics and phylogenetics to identify large sets of single-copy orthologous genes (COSII) for comparative, evolutionary and systematic studies: A test case in the euasterid plant clade. Genetics, 174, 1407-1420. http://dx.doi.org/10.1534/genetics.106.062455 